"Application of environmental management accounting by small and medium enterprises in South Africa"

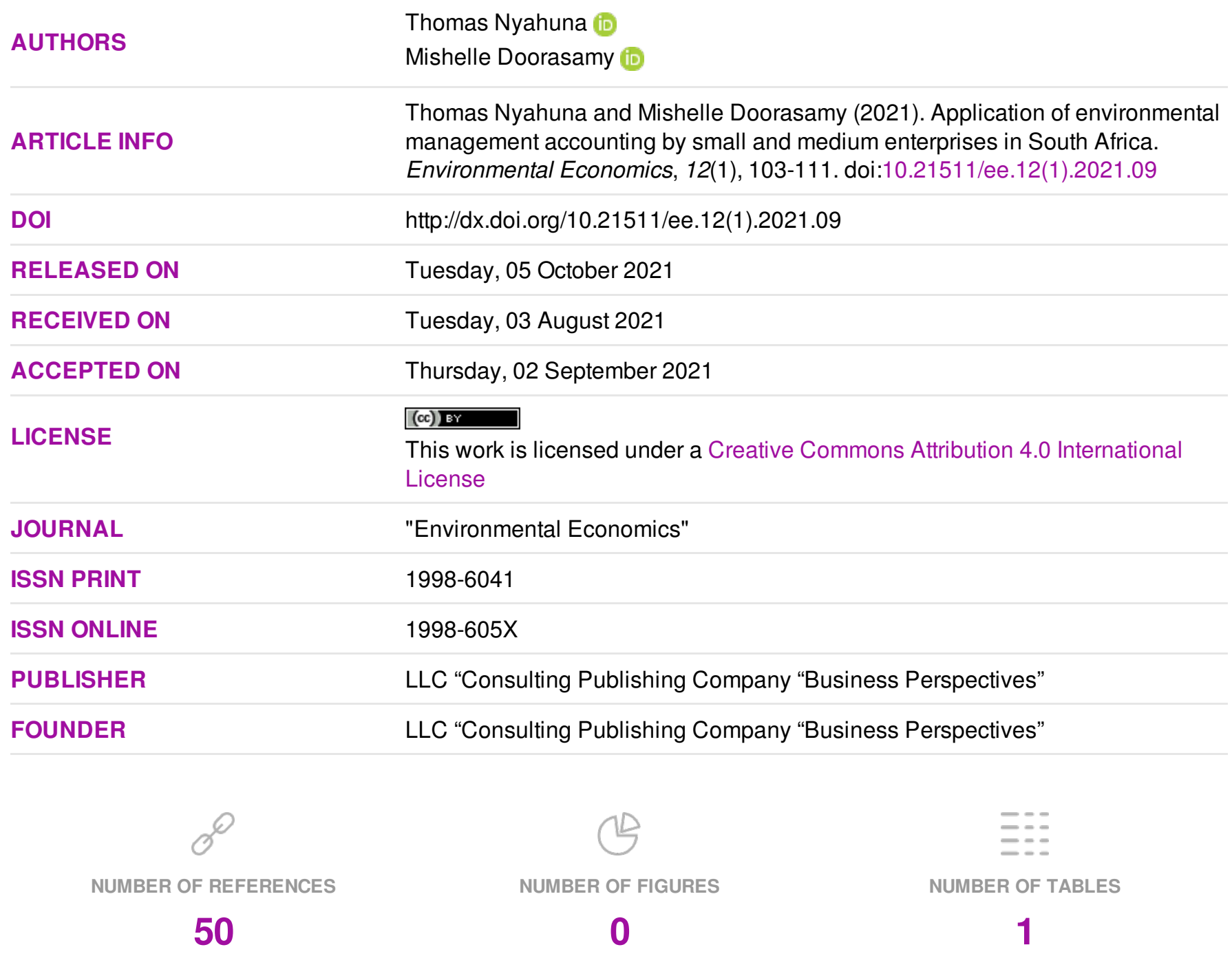

(c) The author(s) 2022. This publication is an open access article. 


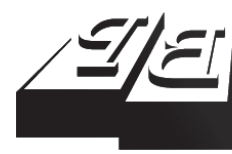

\section{BUSINESS PERSPECTIVES}

(O)

LLC "CPC "Business Perspectives" Hryhorii Skovoroda lane, 10 Sumy, 40022, Ukraine www.businessperspectives.org

Received on: $3^{\text {rd }}$ of August, 2021 Accepted on: $2^{\text {nd }}$ of September, 2021 Published on: $5^{\text {th }}$ of October, 2021

() Thomas Nyahuna, Mishelle Doorasamy, 2021

Thomas Nyahuna, MBA, Bcom Hons Acc., University of KwaZulu Natal, South Africa. (Corresponding author)

Mishelle Doorasamy, Ph.D., Senior Lecturer, University of KwaZulu Natal, South Africa.

\section{APPLICATION OF ENVIRONMENTAL MANAGEMENT ACCOUNTING BY SMALL AND MEDIUM ENTERPRISES IN SOUTH AFRICA}

\begin{abstract}
By focusing on environmental management accounting in SMEs, the study helps SME managers to effectively understand and find better ways of improving environmental management. The paper investigates environmental management accounting applications in manufacturing small and medium enterprises in Gauteng province. Small and medium enterprises were chosen based on their exclusion from the mainstream research on environmental management accounting (EMA). To achieve the main aim of the study, 24 in-depth interviews were undertaken among SMEs' managers, accountants, chief executive officers, and owners. The study found that physical EMA is more common in SMEs than monetary EMA. 77\% of SMEs' respondents confirm using physical environmental information in their operations. Therefore, SMEs prefer EMA practices with little cost or no cost attached and practices that can effectively generate returns in the short term. In addition, the avoidance of monetary EMA is anchored on the premise of avoiding costly projects with no immediate material financial returns. Therefore, EMA is critical for SMEs to achieve sustainability.
\end{abstract}

\section{Keywords}

environmental performance, sustainability, in-depth interviews, environmental costs, financial performance

JEL Classification M41, Q01, Q56

\section{INTRODUCTION}

The world is increasingly worried about environmental issues. This concern creates new problems and compels organizations, including small and medium enterprises (SMEs), to put much attention to environmental matters. Comparing with large companies, SMEs do not effectively manage the environment. Additionally, the role that SMEs perform in stabilizing the environment is still unclear. Extant literature reflects that sustainability in SMEs can be attained through a trade-off between economic, environmental, and social elements of the business operations (Al-Refaie \& Momani, 2018; Rita et al., 2018; Laurinkevičiūtė \& Stasiškienè, 2010). This relationship can be partly achieved through the application of environmental management accounting (EMA). EMA has been defined as a tool that helps companies to manage environmental performance and report environmental information (Herzig et al., 2012).

However, prior studies have been having limitations of failing to empirically validate environmental management practices currently applied by SMEs from an emerging market perspective such as South Africa (Setiawan \& Izzaty, 2021). Literature shows that little is known about the EMA application in SMEs as more focus is on larger companies. The environmental management practices used by SMEs have 
been largely established through theoretical analysis (Famiola \& Wulansari, 2020; Fonseca et al., 2020). This leaves SME managers without adequate and proper empirical justification on how to improve and address their environmental concerns. This is important because addressing environmental issues leads to improved financial performance (Campos, 2012; Famiola \& Wulansari, 2020). Therefore, in a way, understanding environmental management practices applicable to their SMEs is likely to improve the financial performance of SMEs - a key challenge to the existence of SMEs.

Despite a possible financial performance improvement, studies on EMA application among SMEs have received little attention from researchers (Jamil et al., 2015; Fuzi et al., 2020). This leaves a gap in studies on EMA applications by SMEs (Johnstone, 2020). That is to say, there is a lack of empirical studies on EMA application in SMEs. It is unclear how SMEs are using EMA practices. Hence, Mohamed (2018) contends that there is a need for solid empirical evidence on EMA practices in developing countries. In following unheeded calls by Johnstone (2020), and Famiola and Wulansari (2020), it is believed that there is value in the study by focusing on EMA application in SMEs.

\section{LITERATURE REVIEW}

Literature has placed environmental management accounting as one of the new and attractive solutions to address environmental issues within corporate organizations. This is because EMA has been developed to address weaknesses of the traditional management accounting system in administering environmental activities (Gale, 2006; Ferdous et al., 2019; Burrit et al., 2016; Gunarathne \& Lee, 2015). Numerous environmental costs are hidden and allocated as overhead costs under the traditional management accounting system (IFAC, 2005; Huseno, 2018). IFAC (2005) views EMA as not a different accounting system but instead helps to bring about environmental information for sustainability purposes (Jamil et al., 2015; Gibassier \& Alcouffe, 2018). Hence, the development of EMA has attracted a lot of scholarly attention. EMA is defined as the "identification, collection, analysis and use of a broad scope of information for internal decision-making" (Schaltegger \& Burrit, 2000). Despite its conceptualization over two decades ago, EMA has no standard and universal definition yet (Gunarathne \& Lee, 2015). However, EMA application remains unknown in SMEs (Mohamed, 2018).

Understanding the barriers of applying EMA in 350 manufacturing SMEs in Malaysia through a postal survey to managers, Jamil et al. (2015) identified that institutional pressure is vital in SMEs applying EMA tools. SMEs were observed to have a budget allocation and most apply physical than monetary EMA practices to mitigate environmental challenges. Jamil et al. (2015) argued that this suggests that managers in manufacturing SMEs are not motivated enough to adopt EMA practices regardless of undertaking environmental budgets. This supports Jalaludin et al. (2011) observation that companies in Malaysia seem to ignore EMA as a less important component of their internal system.

In addition, Mohamed (2018) found that physical EMA was more common in Malaysian SMEs in comparison to monetary EMA. In designing the questionnaires, the study adopted EMA items extracted from Schaltegger et al. (2012). The SMEs were mostly using life cycle inventories followed by environmental long-term financial planning. Applying regression analysis, Mohamed (2018) report that both physical and monetary EMA had a positive relationship with financial performance. This study is in contrast to Campos (2012) who revealed that SMEs in Brazil were using more monetary than physical EMA.

Zaradat et al. (2021), using questionnaires on 291 SMEs and interviews on 6 SME managers, examined environmental management practices used in SMEs in Jordan. It was found that EMA practices were low within the sampled SMEs. This was explained as emanating from limited financial resources, inadequate experience, and high costs related to EMA implementation. Despite that, the study discloses that the sampled SMEs in Jordan are mostly applying environmental cost information and environmental planning as practices. However, the study is limited to using subjective data to conclude. 
Despite the benefits of EMA, its adoption and implementation remain critically low in companies in developing countries (Susanto \& Meiryani, 2019) like South Africa. In most scenarios, managers are unaware of the value added by enhancing environmental performance and lessening environmental effects (IFAC, 2005; Ferreira et al., 2010; Mohamed, 2018). As a result, numerous prospects to decrease environmental costs are lost (Schaltegger, 2018; Burritt, 2004; Ariffin, 2016). This is a result of low environmental awareness, lack of stakeholders' pressure, and weak environmental laws (Susanto \& Meiryani, 2019; Chathurangani \& Madhusanka, 2019). These weaknesses are more evidenced in SMEs where the migration to management accounting has proven to be practically difficult (Johnson \& Schaltegger, 2016; Susanto \& Meiryani, 2019).

The function and use of EMA in increasing firm performance are well documented in the case of large corporations in industrialized countries. This has seen most of the researchers and scholars associating EMA and its tools with data originating from big companies. EMA in SMEs is still less researched (Jamil et al., 2015; Susanto \& Meiryani, 2019; Sahu et al., 2021) particularly on the use of management practices associated with environmental issues (Susanto \& Meiryani, 2019). This is in direct contrast with Gibassier and Alcouffe's (2018) observation that "we will not achieve sustainability without engaging with SMEs." Available empirical results show that EMA is implemented in various ways and initiatives depending on the industrial sector, size, geography, and management commitment. For instance, Deswanto and Siregar (2018) found that EMA is implemented through environmental audits and cleaner production.

However, prior studies have failed to empirically validate and delve into how EMA is being implemented in SMEs particularly in emerging markets such as South Africa, which has at all been discovered through theoretical or conceptual analysis. Susanto and Meiryani (2019), examining the association between antecedents of EMA and environmental performance in Indonesian SMEs, observe that financial benefit expectation is the main internal drive for EMA uptake. It was further discovered that the SMEs were applying EMA to cover regulatory pressure. However, Johnstone (2020) affirms that much remains to be known about EMA in SMEs. In general, Bartolomeo et al. (2000), Christ and Burritt (2013), and Lee (2011) have submitted that the present EMA practices' implementation still needs to be identified. Though, EMA and sustainability literature on SMEs is still behind compared with large corporations (Gibassier \& Alcouffe, 2018). The lack of EMA studies on SMEs is a problem, as SMEs are not "little big business". This implies that tools designed for larger corporations are ordinarily unable to accommodate SMEs to operationalize (Johnstone, 2020; Mohamed, 2018). Therefore, the main goal of the study is to find how South African manufacturing SMEs are applying EMA in their production processes.

\section{METHODS}

\subsection{Data collection}

This study adopted in-depth interviews focusing on 24 SMEs to collect data. Interviews avail the chance to collect rich descriptive evidence because they afford a good room to raise follow-up questions (Johnstone, 2020). Such as, a certain EMA tool might not be used or used by a particular SME; in-depth field interviews in this case offer itself to sound understanding of why it is happening in such a way than the survey approach. In addition, purposive sampling was used to discriminate manufacturing SMEs based on certain criteria.

SMEs are derived from Gauteng province. Given the absence of research on SMEs' use of EMA, it is imperative to collect sound data and proof from a couple of SMEs as compared to applying an extensive survey methodology at this period. Second, maintaining with Johnson and Schaltegger's (2016) proposition, it was assumed that not all EMA practices or tools may be clearly categorized applying predetermined practices. In this case, certain EMA information may be generated based on geographic location, designed to smoothen the environmental needs of managers in a specific location. Therefore, the in-depth interview approach permits larger latitude to discover EMA practic- 
es adopted by SMEs that lie outside prejudged concepts of what is anticipated to be seen in the application.

The study chose not to focus on micro SMEs (those with fewer than ten employees) as anticipated that SMEs of that magnitude may be more likely not to implement the basics of EMA practices and tools. The study focused on manufacturing SMEs in Gauteng province with at least 11 employees but not more than 500. The manufacturing SMEs were chosen based on the conventional notion that perceives the manufacturing sector as largely responsible for global negative environmental impacts (Das et al., 2020). Also, accountants or finance personnel and chief executive officers/owners were targeted in this study to be able to answer the research questions.

A satisfactory sample of SMEs was used. For example, using in-depth interviews scholars such as Armitage et al. (2016) used a sample of 22 SMEs in their study.

\subsection{Interview process}

To discover EMA practices and initiatives potentially adopted by SMEs, items were adapted from Phan et al. (2017) and IFAC (2005). However, the list was somehow shortened and modified to accommodate SMEs' operations. The interviews were semi-structured. For the EMA tools below, respondents were asked if EMA tools were used (yes/no). If yes, they were asked to further define the extent of usage, and if "no" an explanation was requested to accompany this answer of why not using the EMA tool. After going through the EMA tools during the interview, respondents were questioned if there are any EMA tools not covered by the interview. Lastly, the SMEs' respondents got an opportunity to indicate EMA tools their SMEs were forecasting to use soon in forthcoming periods.

The reliability of collected data was augmented by participants asked similar interview questions. The SMEs respondents were also responsible for re-reading the transcripts for co correctness (Masurel, 2007).

Table 1. Features of engaged SMEs and respondents

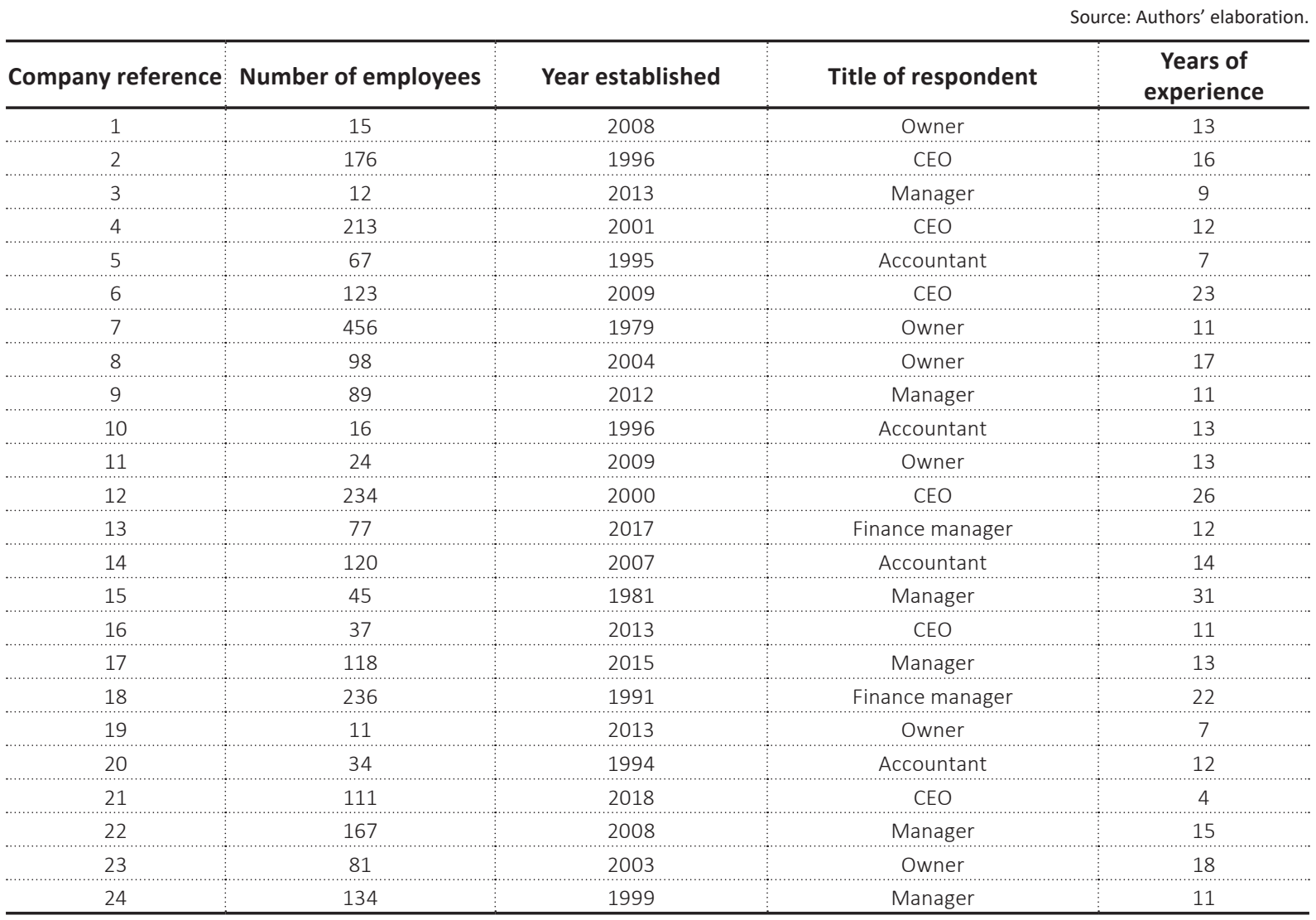

Note: CEO - Chief Executive Officer. 
The interview data were transcribed and analyzed through coding. Thus all results reported emanating from coding of the detailed transcriptions.

To explore EMA practices used by manufacturing SMEs in Gauteng province, Braun and Clarke's (2006) approach of thematic was adopted to evaluate interview data. The six steps include transcribing the data, creating codes, probing themes, revising themes, describing themes, and reporting them.

\section{RESULTS}

\subsection{Use of EMA tools and practices}

This sub-section looks at the results emerging from the 24 in-depth interviews.

The most EMA practice to receive the highest nomination for being used by the sampled SMEs was a recording of physical inputs (energy, water, materials) at $77 \%$. This leaves a marginal $23 \%$ not recording physical inputs. Further, 59\% of the SMEs respondents confirmed using environmental audits. This reflects that environmental audits are key environmental management practices within SMEs. Environmental training was reported at $52 \%$. This means $52 \%$ of the respondents acknowledge using environmental training in their effort to minimize environmental challenges.

However, other EMA practices such as using environmental performance for physical inputs, development, and use of environment-related key performance monetary indicators, identification of environment-related costs, and classification of environment-related costs, and allocation of environment-related costs to products were not popular within sampled SMEs. Respondents confirm within a range of $1 \%$ and $15 \%$ of using these EMA practices within their businesses.

\section{DISCUSSION}

As reflected by the findings, "using environmental performance targets for physical inputs, development and use of environment-related key performance monetary indicators (e.g. reductions in energy costs), identification of environment-re- lated costs, classification of environment-related costs and allocation of environment-related costs to products" (Phan et al., 2017) are not common within manufacturing SMEs in Gauteng. This echoes findings by Nyide (2019) that EMA application remains debated and low in South Africa. However, Jalaludin et al. (2011) explain that the lack of awareness by managers of the benefits and importance of improving environmental issues impedes EMA use. In this case, opportunities for improvement and cost reduction are lost (Chang, 2007; Le et al., 2019).

In addition, the application of cleaner production within SMEs is below expectation. SMEs in general are not using cleaner production within their operations (Das et al., 2020). Cleaner production is viewed as a new concept and with a slow uptake in developing countries (Sahu et al., 2021) such as South Africa (Doorasamy, 2019). However, the finding is also in direct contrast with studies that found the adoption of cleaner production at an advanced stage in SMEs (Susanto \& Meiryani, 2019; Gunarathne \& Sankalpani, 2021). Literature reveals that SMEs are not inclined to exceed beyond the required legal expectations because SMEs lack a holistic outlook on sustainability (Fonseca et al., 2020). In addition, SMEs view cleaner production as an expensive project with no positive returns (Jalaludin et al., 2011; Dey et al., 2018). The finding is consistent with Sahu et al. (2021) who report that, despite the benefits, cleaner production use within small businesses, particularly in emerging markets such as South Africa, remains low. Also, cleaner production when adopted in SMEs lacks integration of all its components due to limited financial capacity, experts, and skilled manpower (Johnson \& Schaltegger, 2016).

SMEs in Gauteng are mostly recording all physical inputs (energy, water, materials) manually. This explains the importance of physical EMA (PEMA) to manufacturing SMEs. Compiling PEMA is cheap and demands a less sophisticated information system. This finding is consistent with the recent studies by Jamil et al. (2015), Mohamed (2018), and Yacob et al. (2019) that SMEs pay more attention to physical than monetary EMA. Prior studies have attributed to both absences of adequate skills (Jalaludin et al., 2011) and limited financial capacity to set up proper accounting information systems (Johnson \& 
Schaltegger, 2016) as factors impeding the collection of monetary information in SMEs.

In this study, environmental audits were confirmed as significant EMA practices. This differs from a study by Armitage et al. (2016) in Canadian SMEs that found environmental audits to be of no significance. However, in South African SMEs the respondents argue that using environmental audits has been necessitated by various workshops by industry leaders in the manufacturing industry and environmental practitioners urging SMEs to follow the cheaper route of using the two as ingredients to address sustainability. This reflects the significance of institutional pressure on SMEs in adopting EMA.

The study finding also reflects a clear picture that monetary environmental information is not widely used in SMEs. This can be partly explained by the absence of formal accounting information systems in SMEs to produce the relevant environmental information (Jamil et al., 2015). Ferreira et al. (2010) found that the absence of EMA guidance leads to low adoption of EMA practices. In this study, development, and use of environment-related key performance monetary indicators (e.g. reductions in energy costs) (Phan et al., 2017) is not popular in 94\% of the respondents, identification of environment-related costs is not used by $88 \%$ of SMEs, and classification of environment-related costs is ignored by $95 \%$ and allocation of environment-related costs to products remains rejected by $99 \%$ of the SMEs. In sum, this indicates that EMA adoption in manufacturing SMEs in South Africa is low and still in the infancy stage because of a dearth of awareness about its financial and environmental benefits.

In addition, to apply cleaner production SMEs need to be convinced of the financial benefits of imple- menting such an exercise (Mohamed, 2018). This calls for broader action from various stakeholders such as government and environmental protection agencies to engage SMEs on the benefits of environmental protection using tools such as cleaner production.

According to the results, the SMEs are conducting environmental audits with $59 \%$ of the respondents confirming this. SMEs believe that this helps improve their marketing strategies as some of their suppliers and customers value initiatives to enhance the environment. The respondents confirmed that it has become a trend with some of their customers, both locally and internationally, requiring some environmental information of the firm.

This position reiterates that institutional pressure can assist in achieving the adoption of EMA in SMEs (Armitage et al., 2016). Importantly, it implies that SMEs are comfortable in aligning themselves to EMA practices that guarantee immediate financial benefits. This shows that SMEs find it easier to incorporate EMA practices that incur no costs or once-off costs as opposed to practices that may result in unpredicted costs such as cleaner production. In this regard, SMEs want EMA tools that recognize them as environmentally friendly by customers and also that generate short-term profit so that they can align it to its effectiveness. Without proper accounting systems, SMEs might not know the long-term benefit of other EMA practices.

In general, the study findings reflect that EMA application is not yet popular by SMEs in developing economies such as South Africa. In similar findings, Jamil et al. (2015), and Mohamed (2018) found that EMA adoption in Malaysian SMEs was low due to a lack of awareness by managers.

\section{CONCLUSION}

EMA implementation practices in South African SMEs have been revealed. This study has been critical in identifying EMA practices within SMEs and how they are being implemented. The study assumes that adequate implementation of EMA practices by the SMEs increases both the financial and environmental performance of the firms. The study was concluded on data from manufacturing SMEs in Gauteng province thus any difference in the context under assessment could alter the results. Hence, the present results need to be probed carefully for application in other backgrounds. The study has in a way contributed to contemporary literature; the study applied and used data from South African SMEs to understand their EMA implementation practices which up to this day has never been undertaken in lit- 
erature. The implication of this study lies on SMEs to reduce environmental impacts through applying EMA practices identified as not currently in use and thus boost economic performance from reduced environmental costs. Further studies can focus on EMA models or frameworks to assist SMEs to adopt sustainable EMA practices from a developing country perspective. In addition, future studies can consider using a quantitative method to overcome challenges grounded in the qualitative research method.

\section{AUTHOR CONTRIBUTIONS}

Conceptualization: Thomas Nyahuna.

Formal analysis: Thomas Nyahuna.

Investigation: Thomas Nyahuna.

Methodology: Thomas Nyahuna.

Project administration: Mishelle Doorasamy.

Software: Thomas Nyahuna.

Supervision: Mishelle Doorasamy.

Validation: Mishelle Doorasamy.

Visualization: Thomas Nyahuna.

Writing - original draft: Thomas Nyahuna.

Writing - review \& editing: Mishelle Doorasamy.

\section{REFERENCES}

1. Al-Refaie, A., \& Momani, D. (2018). ISM approach for modelling drivers to practices of green supply chain management in Jordanian industrial firms. International Journal of Business Performance, 10(2), 91-106. https://doi.org/10.1504/IJBPSCM.2018.098301

2. Aminu, I. M., \& Shariff, M. N. M. (2015). Determines of SMEs performance in Nigeria. Mediterranean Journal of Social Sciences, 6(1), 156-164. http:// dx.doi.org/10.5901/mjss.2015. v6n1p156

3. Ariffin, A. R. M. (2016). Environmental management accounting (EMA): Is there a need? International Journal of Liberal Arts and Social Science, 4(6), 96-103. Retrieved from https://ijlass.org/ data/frontImages/gallery/Vol._4_ No._6/10._96-103.pdf

4. Armitage, H. M., Webb, A., \& Glynn, J. (2016). The use of management accounting techniques by Small and MediumSized Enterprises: A field study of Canadian and Australian practice. Accounting Perspectives, 15(1), 3169. https://doi.org/10.1111/19113838.12089
5. Bartolomeo, M., Bennett, M., Bouma, J., Heydkamp, P., James, P., \& Wolters, T. (2000). Environmental management accounting in Europe: current practice and future potential. The European Accounting Review, 9(1), 31-52. https://doi. org/10.1080/096381800407932

6. Braun, V., \& Clarke, V. (2006). Using thematic analysis in psychology. Qualitative Research in Psychology, 3(2), 77-101. https://doi. org/10.1191/1478088706qp063oa

7. Burrit, R. L., Christ, L. K., \& Varsei, M. (2016). Towards environmental management accounting for trade-offs. Sustainability Accounting Management and Policy Journal, 7(3), 428-448. https://doi.org/10.1108/ SAMPJ-12-2015-0112

8. Burritt, R. L. (2004) Environmental management accounting: Roadblocks on the way to the green and pleasant land. Business Strategy and the Environment, 13(1), 13-32. https:// doi.org/10.1002/bse.379

9. Campos, L. M. S. (2012). Environmental management systems (EMS) for small companies: a study in southern Brazil. Journal of Cleaner Production, 32, 141-148. https://doi. org/10.1016/j.jclepro.2012.03.029

10. Chang, H.-C. (2007). Environmental Management Accounting Within Universities: Current State and Future Potential (Unpublished Ph.D. Thesis). RMIT University. Retrieved from https://core.ac.uk/download/ pdf/15618227.pdf

11. Chathurangani, H. B. P., \& Madhusanka, K. J. S. (2019). Environmental management accounting (EMA)

adoption level among listed manufacturing companies in Sri Lanka: Institutional theory perspective. Research in Social Sciences, 2(1), 1-12. https://doi. org/10.53935/2641-5305.v2i1.11

12. Christ, K. L., \& Burritt, R. L. (2013). Environmental management accounting: The significance of contingent variables for adoption. Journal of Cleaner Production, 41, 163-173. https://doi.org/10.1016/j. jclepro.2012.10.007

13. Das, M., Rangarajan, K., \& Dutta, G. (2020). Corporate sustainability in SMEs: An Asian perspective. 
Journal of Asia Business Studies, 14(1), 109-138. https://doi. org/10.1108/JABS-10-2017-0176

14. Deswanto, R. B., \& Siregar, S. V. (2018). The associations between environmental disclosures with financial performance, environmental performance, and firm value. Social Responsibility Journal, 14(1), 180-193. https://doi. org/10.1108/SRJ-01-2017-0005

15. Dey, K., Petridis, N. E., Petridis, K., Malesios, C., Nixon, J. D., \& Ghosh, S. K. (2018). Environmental management and corporate social responsibility practices of small and mediumsized enterprises. Journal of Cleaner Production, 195, 687702. https://doi.org/10.1016/j. jclepro.2018.05.201

16. Doorasamy, M. (2019). Material flow cost accounting practices and resource efficiencies in South African sugar industry (Ph.D. Thesis). University KwaZulu Natal. Retrieved from https:// researchspace.ukzn.ac.za/handle/10413/17363

17. Famiola, M., \& Wulansari, A. (2020). SMEs' social and environmental initiatives in Indonesia: An institutional and resource-based analysis. Social Responsibility Journal, 16(1), 15-27. https://doi.org/10.1108/SRJ-052017-0095

18. Ferdous, M. I., Adams, C. A., \& Boyce, G. (2019). Institutional drivers of environmental management accounting adoption in public sector water organizations. Accounting, Auditing and Accountability Journal, 32(4), 984-1012. https:// doi.org/10.1108/AAAJ-09-20173145

19. Ferreira, A., Moulang, C., \& Hendro, B. (2010). Environmental management accounting and innovation: An exploratory analysis. Accounting, Auditing and Accountability Journal, 23(7), 920-948. https://doi. org/10.1108/09513571011080180

20. Fonseca, P. C., Ferreira, F. A. F., Pereira, L. F., Govindan, K., \& Meidute-Kavaliauskiene, L. (2020). Analyzing determinants of environmental conduct in small and medium-sized enterprises: A sociotechnical approach. Journal of Cleaner Production, 256, 120380. https://doi.org/10.1016/j. jclepro.2020.120380

21. Fuzi, N. M., Habidin, N. F., Janudin, S. E., \& Ong, S. Y. Y. (2020). Environmental management accounting practices, management system, and performance SEM approach. International Journal of Quality and Reliability Management, 37(9/10), 1165-1182. https://doi. org/10.1108/IJQRM-12-2018-0325

22. Gale, R. (2006). Environmental costs at the Canadian paper Mill: a case study of Environmental Management Accounting (EMA). Journal of Cleaner production, 14(14), 1237-1251. https://doi. org/10.1016/j.jclepro.2005.08.010

23. Gibassier, D., \& Alcouffe, S. (2018). Environmental management accounting: The missing link to sustainability? Social and Environmental Accountability Journal, 38(1), 1-18. https://doi.org /10.1080/0969160X.2018.1437057

24. Gunarathne, N., \& Lee, K. H. (2015). Environmental management accounting (EMA) for environmental management and organizational change: An eco-control approach. Journal of Accounting and Organizational Change, 11(3), 362-383. https:// doi.org/10.1108/JAOC-10-20130078

25. Gunarathne, N., \& Sankalpani, U. (2021). Diffusion of cleaner production in a developing country: The case of Sri Lanka. Journal of Cleaner Production, 311, 127626. https://doi.org/10.1016/j. jclepro.2021.127626

26. Herzig, C., Viere, T., Schaltegger, S., \& Burritt, R. L. (2012). Environmental management accounting: case studies of SouthEast Asian companies. Oxford: Routledge. Retrieved from https://www.routledge.com/ Environmental-Management-Accounting-Case-Studies-of-SouthEast-Asian-Companies/HerzigViere-Schaltegger-Burritt/p/ book/9780415506786
27. Huseno, T. (2018). The environmental management accounting (EMA) perspective calculation of environmental management environment in Riau. Jurnal Aplikasi Management, 16(4), 714-721. https://doi.org/10.21776/ ub.jam.2018.016.04.18

28. IFAC. (2005). International Guidance Document: environmental management accounting. New York: International Federation of Accountants. Retrieved from https://www.ifac.org/system/files/ publications/files/internationalguidance-docu-2.pdf

29. Ismail, N. A., \& King, M. (2014). Factors influencing the alignment of accounting information systems in small and medium sized Indonesian manufacturing firms. Journal of Information Systems and Small Business, 1(1-2), 1-20. Retrieved from https://ojs. deakin.edu.au/index.php/jissb/ article/view/1

30. Jalaludin, D., Sulaiman, M., \& Ahmad, N. N. N. (2011). Understanding environmental management accounting (EMA) adoption: A new institutional sociology perspective. Social Responsible Journal, 7(4), 540-557. https://doi. org/10.1108/17471111111175128

31. Jamil, C. Z., Mahomed, R. Muhammad, F., \& Ali, A. (2015). Environmental management accounting practices in small medium manufacturing firms. Procedia - Social and Behavioral Sciences, 172, 619-626. https://doi. org/10.1016/j.sbspro.2015.01.411

32. Johnson, M. P., \& Schaltegger, S. (2016). Two decades of sustainability management tools for SMEs: how far have we come? Journal of Small Business Management, 54(2), 481-505. https://doi.org/10.1111/ jsbm.12154

33. Johnstone, L. (2020). A systematic analysis of environmental management systems in SMEs: Possible research directions from a management accounting and control stance. Journal of Cleaner Production, 244, 118802. 
https://doi.org/10.1016/j. jclepro.2019.118802

34. Laurinkevičiūtè, T., \& Stasiškienè, M. (2010). Sustainable development decision-making model for small and medium enterprises. Environmental Research, Engineering and Management, 52(2), 14-24. Retrieved from https://erem.ktu.lt/ index.php/erem/article/view/74

35. Le, T. T., Nguyen, T. M. A., \& Phan, T. T. H. (2019). Environmental management accounting and performance efficiency in the Vietnamese construction material industry-A managerial implication for sustainable development Sustainability, 11(19), 5152. https://doi.org/10.3390/ su11195152

36. Lee, K.-H. (2011). Motivations, Barriers, and Incentives for Adopting Environmental Management (Cost) Accounting and Related Guidelines: a Study of the Republic of Korea. Corporate Social Responsibility and Environmental Management, 18(1), 39-49. https://doi.org/10.1002/ csr.239

37. Masurel, E. (2007). Why SMEs invest in environmental measures: sustainability evidence from small and medium-sized printing firms. Business Strategy Environment, 16(3), 190-201. https://doi. org/10.1002/bse.478

38. Maziriri, T., \& Mapuranga, M. (2017). The Impact of Management Accounting Practices (Maps) on the Business Performance of Small and Medium Enterprises within the Gauteng Province of South Africa. Journal of Accounting and Management, 7(2), 12-27. Retrieved from http://journals univ-danubius.ro/index.php/jam/ article/view/4018

39. Mohamed, R. (2018).

Environmental Management Accounting and Environmental Performance. Asia Proceedings of Social Sciences, 1(2), 33-36. https:// doi.org/10.31580/apss.v1i2.339

40. Nyide, C. J. (2019). Better resource management: A qualitative investigation of Environmental Management Accounting practices used by the South African hotel sector. African Journal of Hospitality, Tourism and Leisure, 8(4), 1-10.

41. Phan, T. N., Baird, K., \& Su, S. (2017). The use and effectiveness of environmental management accounting. Australasian Journal of Environmental Management, 24(4), 355-374. https://doi.org/10. 1080/14486563.2017.1354235

42. Rita, D., Ferreira, F., MeiduteKavaliauskiene, I., Govindan, K. \& Ferreira, J. (2018). Proposal of a green index for small and medium-sized enterprises: a multiple criteria group decisionmaking approach. Journal of Cleaner Production, 196, 985996. https://doi.org/10.1016/j. jclepro.2018.05.275

43. Sahu, A. K., Padhy, R. K., Das, D., \& Gautam, A. (2021). Improving financial and environmental performance through MFCA A SME case study. Journal of Cleaner Production, 279, 123751. https://doi.org/10.1016/j. jclepro.2020.123751

44. Schaltegger, S. (2018). Linking environmental management accounting: A reflection on (missing) links to sustainability and planetary boundaries. Social and Environmental Accountability Journal, 38(1), 19-29. https://doi.or g/10.1080/0969160X.2017.1395351

45. Schaltegger, S., \& Burritt, R. (2000). Contemporary Environmental Accounting: Issues, Concepts and Practice. London: Routledge. https://doi. org/10.4324/9781351282529

46. Schaltegger, S., Viere, T., \& Zvezdov, D. (2012). Tapping environmental accounting potentials of beer brewing: Information needs for successful cleaner production. Journal of Cleaner Production, 29-30, 1-10. https://doi.org/10.1016/j. jclepro.2012.02.011

47. Setiawan, E., \& Izzaty, K. N (2021). Analysis of Management Accounting Systems Affecting Energy Efficiency, Environmental Uncertainty and Environmental
Performance of Small and Medium Enterprises. Journal of Applied Sciences in Accounting, Finance, and Tax, 4(1), 77-90. https://dx.doi.org/10.31940/jasafint.v4i1.2432

48. Susanto, A., \& Meiryani, M. (2019). Antecedents of Environmental Management Accounting and environmental performance: Evidence from Indonesian Small and Medium Enterprises. International Journal of Energy Economics and Policy, 9(6), 401-407. https://doi. org/10.32479/ijeep.8366

49. Yacob, P., Wong, S. L., \& Khor, C. S. (2019). An empirical investigation of green initiatives and environmental sustainability for manufacturing SMEs. Journal of Manufacturing Technology Management, 30(1), 2-25. https:// doi.org/10.1108/JMTM-08-20170153

50. Zaradat, Z., Taha, R., Zin, M. R., Zakaria, W. Z. W., \& Aziz, R. A. (2021). The use and implications of management accounting practices in small and mediumsized enterprises. Asia-Pacific Management Accounting Journal, 16(1), 249-295. Retrieved from https://apmaj.uitm.edu.my/images/Vol-16-1/20211-10.pdf 